\title{
Penguraian Limbah Tahu Menggunakan Bakteri dan Plasma Ozonasi
}

\section{(Decomposition of Tofu Waste using Bacteria and Ozonation Plasma)}

\author{
Intan Ayu Zuhaela, Mutiara Regita Cahyani, Teguh Endah Saraswati*, Sentot Budi Rahardjo, Edi \\ Pramono, Sayekti Wahyuningsih, Witri Wahyu Lestari, Dian Maruto Widjonarko
}

Program Studi Kimia, Fakultas Matematika dan Ilmu Pengetahuan Alam, Universitas Sebelas Maret J1. Ir. Sutami 36 A, Kentingan, Surakarta, Jawa Tengah, Indonesia, 57126

*Email: teguh@mipa.uns.ac.id

\begin{abstract}
Abstrak. Limbah tahu merupakan zat yang berbahaya dan memiliki dampak buruk terhadap lingkungan apabila tanpa proses pengolahan terlebih dahulu. Permasalahan ini dapat diatasi dengan melakukan pengolahan limbah tahu menggunakan bakteri sebagai alternatif pembuatan pupuk organik dan treatment plasma ozonasi untuk mengurangi bau. Penelitian ini bertujuan untuk menguraikan limbah tahu sehingga dapat digunakan sebagai pupuk organik, mengurangi bau busuk yang dihasilkan oleh limbah tahu sehingga aman dan mudah diterapkan oleh masyarakat. Pengolahan limbah tahu tersebut dilakukan dengan variasi metode menggunakan bakteri pengurai mikroorganisme efektif dimodifikasi dengan plasma ozonasi dan aerator, serta penambahan antifoam. Pengolahan limbah dengan plasma ozonasi didahului dengan penambahan antifoam. Hasilnya menunjukkan limbah dengan penambahan antifoam dan plasma ozonasi selama 15, 30 dan 60 menit memiliki karakteristik sangat bau dan keruh. Penambahan bakteri, molase dengan treatment tanpa dan dengan ozonasi selama 14 hari menunjukkan karakteristik yang agak berbeda dengan bau yang agak berkurang dengan sebelumnya tetapi masih sangat keruh. Penambahan $\mathrm{EM}_{4}$ treatment plasma dikombinasi dengan plasma ozonasi memberikan karakteristik yang paling baik dengan bau dan kekeruhan yang jauh berkurang.
\end{abstract}

Kata kunci: bakteri, degradasi, limbah tahu, plasma, ozonasi.

Abstract. Tofu waste is a dangerous substance and had a bad impact on the environment if without not be processed. This problem can be resolved by treating tofu waste using bacteria as an alternative for making organic fertilizers and treating plasma ozonation to reduce odor. The study aims to describe the tofu waste thus it can be used as organic fertilizer, reducing the bad smell produced by tofu waste which is safe and easy for the community to apply. The tofu waste treatment has been treated with a variety of methods using bacteria that decompose microorganisms effectively modified with ozonation plasma and aerators, as well as the addition of antifoam. The waste treatment with ozonated plasma has been processed by the addition of antifoam. The results showed that the waste with the addition of antifoam and ozonation plasma for 15,30, and 60 minutes had a very odor and cloudy characteristics. The addition of bacteria, molasses treated without and with ozonation for 14 days showed that the tofu wastes have different characteristics with a slightly reduced odor but are still very cloudy. The addition of EM4 plasma treatment combined with ozonated plasma gave the best characteristics with significantly reduced odor and turbidity.

Keywords: bacteria, degradation, ozonation, plasma, tofu waste 


\section{Pendahuluan}

Tahu merupakan salah satu makanan olahan kedelai [1]. Pembuatan tahu terdiri dari beberapa proses, yaitu perendaman, penggilingan kedelai, pemasakan dan pembungkusan tahu. Berbagai proses produksi tahu tersebut mengakibatkan timbulnya limbah industri tahu. Perkiraan jumlah limbah tahu yang dihasilkan dari $100 \mathrm{~kg}$ kedelai adalah sebesar 1,5 - $2 \mathrm{~m}^{3}$ [2]. Limbah yang dihasilkan dari pabrik tahu dapat berupa limbah padat dan limbah cair. Limbah padat tahu akan diolah menjadi tempe gembus, kerupuk dan sebagai pakan ternak. Sedangkan Limbah cair tahu langsung dibuang tanpa pengolahan. Limbah cair tahu mengandung padatan tersuspensi maupun zat terlarut yang akan mengalami perubahan kimia, fisika dan biologis. Air limbah industri pembuatan tahu merupakan salah satu sumber pencemar lingkungan karena mempunyai kadar polutan yang tinggi [3].

Banyaknya zat pencemar yang terkandung dalam limbah tahu seperti fosfor, kalsium, mangan [4], Total suspended solid (TSS), Chemical Oxygen Demand (COD) dan Biological Oxygen Demand (BOD). TSS, COD dan BOD akan menyebabkan terganggunya lingkungan perairan, karena menurunnya kadar oksigen dalam air [5]. Kandungan BOD dan COD pada limbah tahu sebesar 5643 - $6870 \mathrm{mg} / \mathrm{L}$ dan 6870 $10500 \mathrm{mg} / \mathrm{L}$ [6]. Angka BOD dan COD yang tinggi disebabkan karena adanya protein dan zat organik yang terkandung pada limbah tahu. Kadar tersebut sangat tinggi apabila dibandingkan dengan Peraturan Menteri Negara Lingkungan Hidup nomor 15 tahun 2008 tentang baku mutu air limbah bagi usaha dan atau kegiatan pengolahan kedelai. Permasalahan pencemaran lingkungan oleh limbah cair tahu dapat diatasi dengan melakukan pengolahan pada limbah tahu seperti dengan menggunakan bakteri dan treatment plasma ozonasi. Penambahan bakteri mikroorganisme efektif pada limbah cair tahu akan mengubah limbah cair tahu menjadi pupuk organik, karena limbah cair tahu memenuhi unsur hara yang terdapat pada tanah, sehingga dapat bermanfaaat bagi proses pertumbuhan tanaman [4], sedangkan treatment plasma ozonasi pada limbah cair tahu akan mengurangi kadar bau dari limbah cair tahu.

\section{Metode}

2.1. Pengolahan limbah tahu dengan treatment ozonasi

Limbah tahu sebanyak 1L yang ada dalam jerigen ditambah dengan 20 tetes antifoam kemudian dikocok. Limbah tahu tersebut kemudian dilakukan treatment ozonasi selama 0, 15, 30 dan 60 menit. Limbah tahu kemudian diuji secara organoleptik untuk mengamati perubahan yang terjadi.

\subsection{Pengolahan limbah tahu menggunakan $E_{4}$}

Limbah tahu sebanyak masing-masing 1L sebanyak 2 jerigen ditambah dengan $1 \mathrm{~mL} \mathrm{EM}_{4}$ dan 20 tetes antifoam pada setiap jerigen kemudian di kocok. Limbah tahu kemudian dilakukan treatment menggunakan plasma ozonasi selama 60 menit dan aerator selama 1 menit. Uji organoleptik pada limbah tahu hasil treatment dilakukan pada hari ke $0,3,5$ dan 7.

\subsection{Pembuatan pupuk cair dari limbah tahu}

Limbah tahu sebanyak masing-masing 1L sebanyak 2 jerigen ditambah dengan $20 \mathrm{~mL} \mathrm{EM}_{4}, 20$ $\mathrm{mL}$ molase, pada salah satu jerigen ditambah dengan 15 tetes antifoam dan tanpa pemberian antifoam pada jerigen yang lain. Treatment plasma ozonasi selama 60 menit dilakukan pada jerigen dengan penambahan antifoam, sedangkan treatment aerator selama 1 menit. Kedua jerigen dibiarkan selama 14 hari kemudian dilakukan uji organoleptik.

\section{Hasil dan Pembahasan}

Salah satu aplikasi pengolahan limbah cair tahu adalah digunakan sebagai pupuk organik cair. Penggunaan pupuk organik cair dapat mengurangi jumlah limbah tahu yang dibuang ke lingkungan, serta dapat meningkatkan aktivitas biologi tanah. Pupuk organik menyediakan sumber hara makro (N, P, K, Ca, 
$\mathrm{Mg}$ dan S) serta sumber hara mikro ( $\mathrm{Zn}, \mathrm{Cu}, \mathrm{Mo}, \mathrm{Co}, \mathrm{B}, \mathrm{Mn}$ dan $\mathrm{Fe}$ ). Pupuk organik juga dapat memperbaiki struktur tanah, memperbaiki distribusi ukuran pori tanah dan mengurangi fluktuasi suhu tanah. Pupuk organik juga dapat menjadi sumber energi dan makanan bagi fauna dalam tanah [7]. Penambahan mikroorganisme efektif $\left(\mathrm{EM}_{4}\right)$ yang mengandung lima golongan bakteri pokok seperti fotosinteteik, lactobacillus sp, streptomices sp, ragi (yeast) dan actinomictes [8]. Bakteri pokok tersebut diharapkan dapat menyuburkan tanah dan meningkatkan pertumbuhan tanaman. $\mathrm{EM}_{4}$ juga dapat mempercepat pertumbuhan mikroorganisme yang menguntungkan seperti bakteri pelarut phosphate, menekan pertumbuhan jamur dan mengurangi penggunaan pestisida [9]. Sampel limbah tahu pada hari ke1 dan hari ke-8 ditunjukkan pada Gambar 1 dan Gambar 2. Hasil uji organoleptik pada limbah tahu ditunjukkan pada Tabel 1 dan diringkas pada Gambar 3.

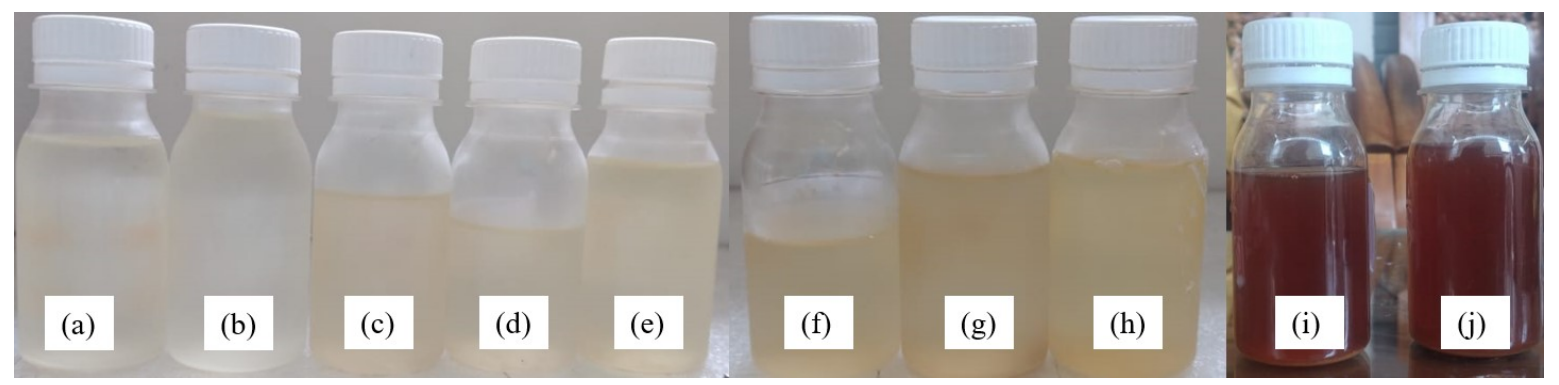

Gambar 1. Sampel limbah tahu pada hari ke-1 (a) limbah fresh; (b) limbah untreated; (c) limbah treatment plasma ozonasi 15 menit; (d) limbah treatment plasma ozonasi 30 menit; (e) limbah treatment plasma ozonasi 60 menit; (f) limbah $+\mathrm{EM}_{4}$ untreated; (g) limbah $+\mathrm{EM}_{4}$ aerator; (h) limbah $+\mathrm{EM}_{4}$ ozonasi; (i) limbah $+\mathrm{EM}_{4}+$ molase aerator; (j) limbah $+\mathrm{EM}_{4}+$ molase ozonasi.

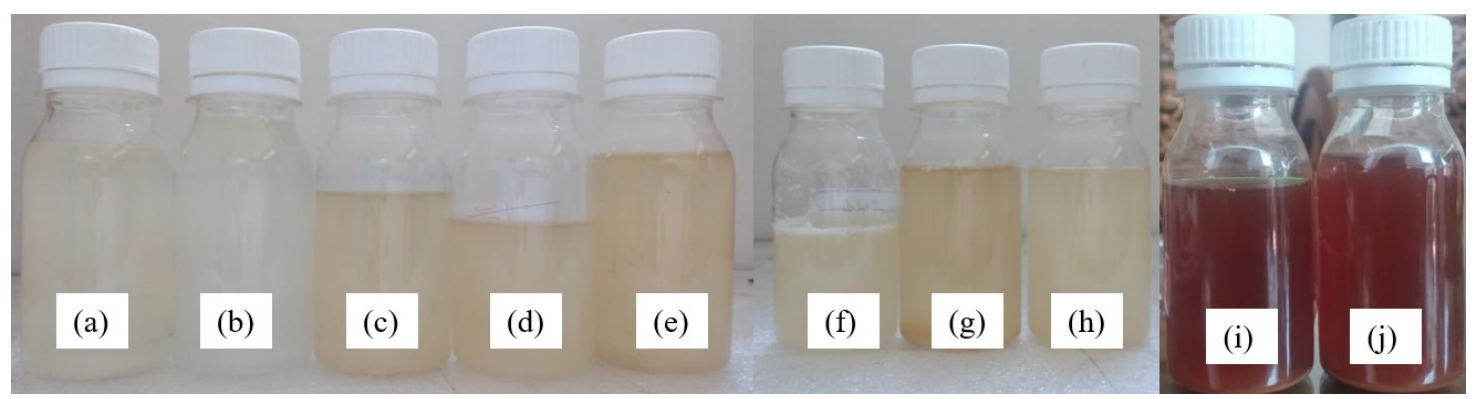

Gambar 2. Sampel limbah tahu pada hari ke-8 (a) limbah fresh; (b) limbah untreated; (c) limbah treatment plasma ozonasi 15 menit; (d) limbah treatment plasma ozonasi 30 menit; (e) limbah treatment plasma ozonasi 60 menit; (f) limbah $+\mathrm{EM}_{4}$ untreated; (g) limbah $+\mathrm{EM}_{4}$ aerator; (h) limbah $+E_{4}$ ozonasi; (i) limbah $+E_{4}+$ molase aerator; (j) limbah $+E_{4}+$ molase ozonasi.

Tabel 1. Hasil uji organoleptik limbah tahu.

\begin{tabular}{|c|c|}
\hline \multirow{2}{*}{ Sampel } & Uji Organoleptik \\
\hline & Bau \\
\hline
\end{tabular}




\begin{tabular}{lcc}
\hline Limbah fresh & Bau & Keruh \\
Limbah untreated & Bau & Keruh \\
Limbah treatment plasma ozonasi $15 "$ & Sangat bau & Keruh \\
Limbah treatment plasma ozonasi $30 "$ & Agak bau & Agak keruh \\
Limbah treatment plasma ozonasi $60 "$ & Agak bau & Agak keruh \\
Limbah $+\mathrm{EM}_{4}$ untreated & Sangat bau & Sangat keruh \\
Limbah $+\mathrm{EM}_{4}$ aerator & Bau & Keruh \\
Limbah $+\mathrm{EM}_{4}$ Ozonasi & Agak bau & Agak keruh \\
Limbah $+\mathrm{EM}_{4}+$ molase aerator & Sangat bau & Sangat keruh \\
Limbah $+\mathrm{EM}_{4}+$ molase ozonasi & Sangat bau & Sangat keruh \\
\hline
\end{tabular}

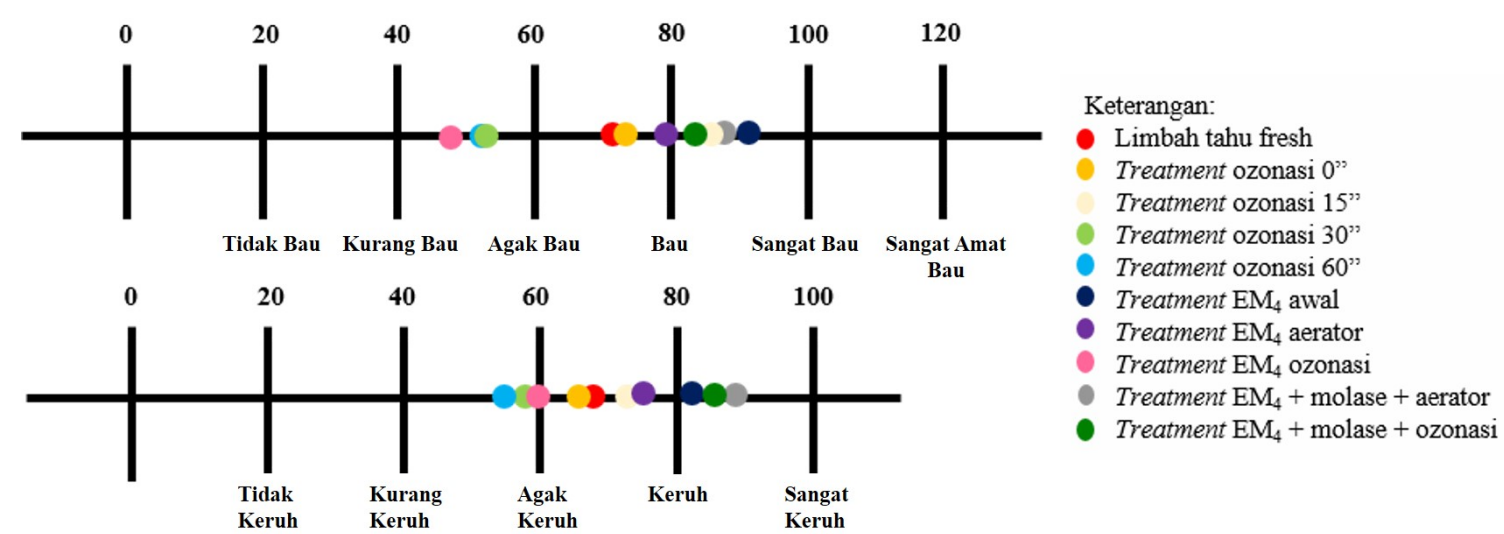

Gambar 3. Hasil uji organoleptik bau dan warna pada limbah tahu.

Limbah tahu setelah melalui treatment plasma ozonasi akan menghasilkan kadar bau yang berkurang apabila dibandingkan dengan tanpa treatment plasma ozonasi, hal ini disebabkan karena terdapat spesies aktif yang dihasilkan dari plasma ozonasi berupa oksidan kuat dapat mengoksidasi senyawa organik yang terkandung dalam limbah tahu cair. Tumbukan elektron dan ion dari plasma akan mengakibatkan terjadinya reaksi redoks seperti yang ditunjukkan pada Persamaan 1-7.

$$
\begin{aligned}
& 2 \mathrm{C}+\mathrm{O}_{2} \rightarrow 2 \mathrm{CO} \\
& 2 \mathrm{CO}+\mathrm{O}_{2} \rightarrow 2 \mathrm{CO}_{2} \\
& \mathrm{H}^{+}+\mathrm{OH}^{-} \rightarrow \mathrm{H}_{2} \mathrm{O} \\
& 2 \mathrm{H}_{2}+\mathrm{O}_{2} \rightarrow 2 \mathrm{H}_{2} \mathrm{O} \\
& \mathrm{OH}+\mathrm{OH} \rightarrow \mathrm{H}_{2} \mathrm{O}_{2} \\
& 2 \mathrm{H}^{+}+2 \mathrm{e}^{-} \rightarrow \mathrm{H}_{2} \\
& \mathrm{~N}_{2}+\mathrm{O}_{2} \rightarrow 2 \mathrm{NO}
\end{aligned}
$$

\section{Kesimpulan}

Penggunaan bakteri dan plasma ozonasi dapat dijadikan sebagai metode alternatif untuk pengolahan limbah cair tahu. Adanya bakteri yang dapat mengubah limbah cair tahu menjadi pupuk organik, serta plasma ozonasi dapat menguraikan polutan organik yang terdapat pada limbah tahu untuk membuat limbah tahu aman apabila dibuang ke lingkungan. 


\section{Referensi}

[1] Bija S., Yulma Y., Aldian A., Akbar A., 2019, Analisa Perubahan Turbiditas pada Limbah Cair Industri Tahu Menggunakan Kitosan dari Limbah Sisik Ikan Banden, J. Harpodon Borneo, 12(1): 42-47.

[2] Handayani T., Niam M. A., 2018, Pemanfaatan Limbah Tahu Sebagai Pupuk Cair Organik dan Es Krim untuk Meningkatkan Pendapatan dan Pengembangan Produk, J Dedikasi, 15: 100-106.

[3] Sulistiyawati I., Rahayu N.L., Purwitaningrum F.S., 2020, Produksi Biolistrik Menggunakan Microbial Fuel Cell (MFC) Lactobacillus bulgaricus dengan Substrat Limbah Tempe dan Tahu, Majalah Ilmiah Biologi Biosfera: a Scientific Journal, 37(2): 112-117.

[4] Faisal M., Mulana F., Gani A., Daimon H., 2015, Physical and Chemical Properties of Wastewater Discharged from Tofu Industries in Banda Aceh City Indonesia, Research $J$ of Pharmaceutical, Biological, and chemical Sciences, 6(4): 1053-1058.

[5] Setiyono S., Yudo S., 2008, Dampak Pencemaran Lingkungan Akibat Limbah Industri Pengolahan Ikan di Muncar (Studi Kasus Kawasan Industri Pengolahan Ikan di Muncar-Banyuwangi), JAI, 4(1): 68-81.

[6] Pradana T.D., Suharno S., Apriansyah., 2018, Pengolahan Limbah Cair Tahu untuk Menurunkan Kadar TSS dan BOD, $J$ Vokasi Kesehatan, 4(2): 56-62.

[7] Hartatik W., Husnain, Widowati, L. R., 2015, Peranan Pupuk Organik dalam Peningkatan Produktivitas Tanah dan Tanaman, J Sumber Daya Lahan, 9(7): 107-120.

[8] Meriatna M., Suryati S., Fahri A., 2019, Pengaruh Waktu Fermentasi dan Volume Bio Aktivator EM4 (Effective Microorganisme) pada Pembuatan Pupuk Organik Cair (POC) dari Limbah BuahBuahan, J Teknologi Kimia Unimal, 7(1): 13-29.

[9] Siswati N.D., Theodorus H., Saputra, P. W. E., 2009, Kajian Penambahan Effective Microorganisms (EM4) pada Proses Dekomposisi Limbah Padat Industri Kertas, Buana Sains, 9(1): 63-68. 